\title{
The Islamic Economic Law Perspective on Sharia Mutual Fund Investment
}

\author{
Risfiana Mayangsari \\ IAIN Bengkulu \\ Email: risfiana@iainbengkulu.ac.id
}

\begin{abstract}
The tendency of Indonesian people to invest, which has recently been increasing, has made these people more selective in determining their investment choices and goals. One of the choices of Indonesian people in investing is sharia mutual funds. Because fundamentally sharia mutual fund investment does not violate the boundaries of sharia and remains in the corridor of Islam, thus investment activity is a form of muamalah (civil) activity in Islam. So, this article aims to explain Islamic mutual fund investment in the perspective of Islamic economic law. This article is based on library research; the data in this study is documentary data in the form of books, articles and notes related to the theme of Islamic mutual funds investment in the perspective of Islamic economic law. So, the conclusion is that Islamic mutual funds in the management and investment policies refer to Islamic law. Regulations for sharia mutual funds in Indonesia are contained in positive law, both conventional and those based on sharia principles are the same, namely regulated in Law No. 8 of 1995 concerning the Capital Market and technical regulations in the form of Government Regulations, Decree of the Minister of Finance, and regulations issued by Bapepam and regulations issued by the Stock Exchange as Self Organitation Regulatory, Fatwa of the National Sharia Council No.20 / DSN-MUI / IV / 2001 regarding Islamic mutual funds. Keywords: Investment, mutual funds, sharia law.
\end{abstract}

Abstrak: Kecendrungan masyarakat Indonesia dalam berinvestasi yang akhir-akhir ini semakin meningkat, menjadikan masyarakat tersebut lebih selektif dalam menentukan pilihan dan tujuan berinvestasi. Salah satu pilihan masyarakat Indonesia dalam berinvestasi adalah reksadana syariah. Karena, secara fundamental investasi reksadana syariah tidak melanggar batasan syariah dan tetap pada koridor Islam, sehingga dengan demikian kegiatan investasi tersebut merupakan bentuk kegiatan muamalah (keperdataan) dalam Islam. Maka artikel ini bertujuan untuk menjelaskan investasi reksadana syariah daam perspektif hukum ekonomi syariah. Artikel ini berbasis penelitian pustaka, data dalam penelitian ini adalah data dokumentasi berupaka buku-buku, artikel, dan catatan-catatan yang berhubungan dengan tema investasi reksadana syariah dalam perspektif hukum ekonomi syariah. Maka, kesimpulnnya adalah reksadana syariah dalam pengelolaan dan kebijakan investasinya mengacu pada syariat Islam. Pengaturan reksadana syariah di Indonesia tertuang dalam hukum positif, baik yang konvensional maupun yang berdasarkan Prinsip syariah adalah sama yaitu diatur dalam Undang-Undang No. 8 Tahun 1995 tentang Pasar Modal dan peraturan teknis berupa Peraturan Pemerintah, Keputusan Menteri Keuangan, dan peraturan-peraturan yang dikeluarkan oleh Bapepam dan peraturan-peraturan yang dikeluarkan oleh Bursa Efek selaku Self Organitation Regulatory, Fatwa Dewan Syariah Nasional No.20/DSN-MUI/IV/2001 tentang reksadana syariah.

Kata-kata kunci: Investasi, reksadana, hukum syariah. 


\section{Introduction}

Facing the global era where the world reality is fast paced and sophisticated, have a profound impact on the economic aspect, which is marked by the increasing of open global market, quality of production, the development of various kinds of products, the increasing of prices for necessities, fostering public awareness to invest, the investment objective is not only to prepare for unlimited needs, but also to anticipate that the money owned is not eroded by inflation.

Investment is a form of utilizing funds that can generate income for fund owners. Investment is a solution for owners of capital in developing their assets, and investing can be made by the owner of the capital himself or submitted to other parties for investment. The allocation of capital to other parties can be channeled to individuals who are individual or channeled to institutions or business entities. Investments take various forms, for example deposits, stocks, bonds, and mutual funds. One form of sharia investment that is currently developing is sharia mutual funds. Currently, Islamic mutual funds are an attractive investment for people who want to invest in accordance with sharia. Mutual funds are an alternative investment that only places funds with debtors who do not violate sharia boundaries, in company fundamentals and operations, according to the fatwa of the Indonesian Ulema Council.

Mutual funds are a forum where the public can invest their funds and by the manager (investment manager) the funds are invested in a securities portfolio. Sharia mutual funds are an investment vehicle that combines Islamic stocks and bonds in one product that is managed by an investment manager. Investment managers offer sharia mutual funds to interested investors, then the funds will be managed by the investment manager to invest in Islamic stocks or bonds that are considered profitable. Investment activities that breathe Islam, especially Islamic mutual funds will be attractive, especially giving the belief that investment activities are also a form of muamalah (civil) activities in Islam.

Sharia mutual funds can be used as an alternative for Indonesian people who are predominantly Muslim to participate in the capital market in a halal way, according to religious law. Because the interest of the Muslim community in investing is not only influenced by financial knowledge, but also by religious factors. This is consistent with the research conducted by Haddad Adjie Pratama in his writing entitled "Public Interest in Sharia Mutual Funds: The Role of Religiosity, Financial Literacy and Income" which states that religiosity has a positive effect on people's interests, while financial literacy and income have no positive effect on interest Public. This article will explain how the perspective of sharia law on Islamic mutual fund investment. The research used in this research is library research, which makes books, articles, laws and fatwas related to sharia mutual fund 
investment and sharia law as the main reference, as well as other data that is still relevant to the research theme as secondary data in this article.

\section{The Legal Basis and Mechanism of Sharia Mutual Funds}

\section{The Sharia mutual funds}

Sharia mutual funds were first introduced in 1995 by the National Bank in Saudi Arabia under the name Global Trade Equity, with capital capitalization of US \$ 150 million. Meanwhile in Indonesia, mutual funds have been known since the raise of Law Number 8 of 1995 concerning the Capital Market and the issuance of corporate mutual funds by PT-BDNI mutual funds in 1995. Then, in 1996 Bapepam issued a regulation on mutual funds in the form of a Collective Investment Contract (KIK). This regulation provides an opportunity for the birth of a sharia mutual fund which was implemented for the first time in 1998 which was managed by PT Danareksa Investment Management, which in that time PT Danareksa issued a sharia-based mixed mutual fund product called Danareksa Syariah Balanced. ${ }^{1}$

The emergence of the first Islamic mutual funds in Indonesia in 1998 managed by PT. Danareksa Investment Management (DIM) is the beginning of Islamic instruments development in the capital market. Furthermore, on July 3, 2000, the Jakarta Stock Exchange (BEJ) together with PT Danareksa Investment Management (DIM) launched the Jakarta Islamic Index (JII) which includes 30 types of shares from issuers whose business activities comply with the provisions concerning sharia law. The criteria for the JII component are prepared based on the approval of the DIM Sharia Supervisory Board (DPS). With this index, it is expected to increase the investor confidence in developing investment in sharia.

In literal terms, the definition of mutual funds according to Law Number 8 of 1995 concerning the Capital Market, mutual funds are "a media used to raise funds from the investor community, to be subsequently reinvested in the form of a securities portfolio by an investment manager." There are three points related to this definition; (1) the existence of funds from the investor community; (2) the funds are invested in a portfolio of securities; (3) the fund is managed by an investment manager. Thus, the funds in mutual funds are funds shared by investors, while the investment manager is the party entrusted to manage these funds. ${ }^{2}$

Meanwhile in the MUI DSN Fatwa No. 20 / DSN / MUI / IX / 2000 defines sharia mutual funds as mutual funds that operate according to the provisions and principles of Islamic sharia, both in the form of contracts

1 Abdul Manan, Aspek Hukum dalam Penyelenggaraan Investasi di Pasar Modal Syariah Indonesia, Jakarta: Kencana, 2009, p. 150.

2 Ibid, hlm.150 
between investors as property (shahib al-mal/rabb al-mal) with investment managers as representatives of shahib al-mal, as well as between investment managers as shahib al-mal and investment users ${ }^{3}$. In another sense, sharia mutual funds are mutual funds whose management and investment policies refer to Islamic law, for example not investing in stocks or bonds from companies whose management or products are contrary to Islamic law. The difference between Islamic mutual funds and conventional mutual funds is that there are two stages of the process that must be passed: a) The screening process, namely the filtering of investment instruments based on sharia guidelines; b) The cleansing process, which is to clean income that is considered to be obtained from activities that are forbiden according to sharia guidelines.

Matters related to sharia mutual funds are as follows: a) Mudharabah (qirad) contract, which is a contract or system in which a person gives his/her assets to another person to be managed provided that the benefits obtained (from the management result) are shared between the two parties , while the loss is borne by Shahib al-mal as long as there is no negligence from the mudharib; b) Prospectus, which is any written information relating to a Public Offering with the aim of other parties to buy Securities; c) Custodian Bank, which is a party whose business activities are to provide custodian services for Securities and other assets related to Securities and other services, including receiving dividends and other rights, completing Securities transactions, and representing account holders who are their clients. ${ }^{4}$

There are steps that should be taken by investors who wish to invest through mutual funds. They are (a) Reading and understanding the contents of the prospectus issued by mutual fund institutions, and reading the contents regarding the procedures for buying and selling back participation units; (b) Knowing the risk profile of investing through mutual funds in addition to the potential benefits; (c) Knowing self-risk profile; (d) Fill in the opening account form and the first order form (subscription form) completely and correctly by attaching a photocopy of valid identity and attaching the specified stamp. (e) Submit a deposit of funds (minimum first deposit and next deposit) plus a subscription fee; (f) After the fund is deposited into the predetermined account, an auto debit will be performed to the sharia mutual funds account in accordance with the applicable regulations.

\footnotetext{
3 Ibid, p.166

${ }^{4}$ Hasbi Umar, Filsafat Fiqh Muamalat Kontemporer, Jakarta: PT. Raja Grafindo Persada, 2014, p. 305.
} 
Regarding the mechanism of financial transactions through Islamic mutual fund institutions, it can be briefly explained as follows: ${ }^{5}$ 1) Investors get participation units from the investment manager after depositing funds to the custodian bank first; 2) The investment manager receives funds from investors through a custodian bank, so the investment manager is obliged to hand over the unit to investors; 3) Bapepam is the agency authorized to supervise business activities carried out by investment managers regarding their operational activities; 4) The bank then as mentioned above is the party that acts as the intermediary between the investor and the investment manager; 5) The portfolio collected by the investment manager will be managed to make transactions in the capital market to buy securities, which can be in the form of deposits, SBIs, bonds, stocks, and so on; 6) The government or the private sector is an entity that requires capital/additional capital to securities issue to be sold to the public through the capital market ${ }^{6}$.

Sharia mutual funds in Indonesia that are widely issued today are open mutual funds in the form of Collective Investment Contracts (KIK), such as: PNM Syariah, Danareksa Syariah Balanced, Rifan Syariah, and Amanah Syariah mutual funds. In sharia mutual funds, investment managers and custodian banks enter into a contract according to the Capital Market Law known as a Collective Investment Contract.

In the KIK contract, the investment manager and custodian bank bind themselves for the benefit of the investor community to open a platform where the investor community can place their funds in mutual funds and obtain participation units. The fund will be placed in the securities portfolio by the investment manager in accordance with the mandate stated in the contract. Funds which are joint assets owned by mutual fund investors, or commonly referred to as unit unit holders, will be kept by the custodian bank ${ }^{7}$. In mutual fund operations, the custodian bank will receive instructions from the investment manager to complete investment activities decided by the investment manager.

Therefore, the important thing in sharia mutual funds is the issue of the contract. Because, even though the practical considerations of investors do not bring in KIK directly, because before investing in mutual funds investors are required to read the prospectus and sign the application form for participation in mutual funds, it can be considered that investors are bound by the contract.

${ }^{5}$ Abdul Manan, Aspek Hukum dalam Penyelenggaraan Investasi di Pasar Modal Syariah Indonesia, 2009, p. 168.

${ }^{6} \mathrm{Ibid}, \mathrm{hlm} .169$.

7 Alvien Septian Haerisma, Pengantar Reksadana Syariah Introduction of Islamic Mutual Fund, p. 3. 


\section{Legal Basis for Sharia Mutual Funds}

From Islamic perspective, mutual funds are included in the framework of muamalat in Islam. According to Islamic law, basically everything in muamalat is permissible as long as it is not contrary with sharia ${ }^{8}$. In carrying out sharia mutual fund investment activities, you can do anything as long as it does not conflict with sharia, including illegal investments that cannot be made in the fields of gambling, prostitution, pornography, forbidden food and drinks, ribawi financial institutions, and others as determined by DPS.

Basically, everything in muamalat is allowed as long as it is not contrary to sharia, and in conducting business transactions, the most important thing in Islamic law (muamalat) is the contract. Allah SWT commands the believers to fulfill their contract as in stated Qur'an Surah AlMaidah verse 1 which means: "O believers! Fulfil your promises. Lawful (Cattle) are made unto you, the animals having no speaking power.Save those which shall be narrated to you further, but do not consider the hunting being lawful when you are in pilgrim garb. Undoubtedly, Allah commands what $\mathrm{He}$ wills."9

The conditions that occur in a contract are the conditions determined by the Muslims themselves, as long as it is not contrary to Islamic law. Rasulullah SAW gave the limitation in a hadith which means: "Peace are allowed among Muslims except peace that forbids what is halal or what is haram. Muslims are obliged to meet the conditions they agree on except the conditions that are halal or allow the haram. ${ }^{10}$

The principle in covenant must also follow the law that has been outlined by Allah SWT, as stated in Qur'an Surah An-Nisa verse 29 which means: Let those fear (be anxious for the rights of the orphans) who, if they (themselves) were to leave behind weak offspring, would be fearful on their account and let them keep from disobedience to God for fear of His punishment, and let them speak the truth and proper words (in respect of the division of the inheritance and their treatment of the orphans). ${ }^{11}$ The contract made by the sharia mutual fund with emiten can be conducted through mudharabah (qiradh) / musyarakah. Islamic shareholders who in this case act as mudharib in relation to investors can perform mudharabah contract (qiradh)/musyarakah. ${ }^{12}$

${ }^{8}$ Muhammad, Dasar-dasar Keuangan Islami, Yogyakarta: Ekonisia, 2004, p. 187.

${ }^{9}$ Muhammad Saifuddin, Terjemah Tafsir Perkata, Bandung: Sygma, 2010, p. 106.

${ }^{10}$ HR. Abu Daud, Ibnu Majah dan Tirmizy dari Amru bin 'Auf, lihat Abdul Manan, Aspek Hukum dalam Penyelenggaraan Investasi di Pasar Modal Syariah Indonesia, p.164.

${ }^{11}$ Saifuddin, Terjemah Tafsir Perkata, hlm. 78.

12 Abdul Manan, Aspek Hukum dalam Penyelenggaraan Investasi di Pasar Modal Syariah Indonesia, p. 172. 


\section{Sharia Mutual Fund Mechanism}

In a mutual fund contract, it involves two parties, each of which has certain rights and obligations. The relationship between parties in mutual funds is not a creditor and debtor relationship, but a partnership relation between investors and the investment manager who acts as a fund manager (mudharib). ${ }^{13}$

In its working mechanism there are three parties involved in funds management:

a. Investment manager as a person who manage the investment. This investment manager is responsible for investment activities, which include analysis and selection of investment types, making investment decisions, monitoring the investment market, and takes necessary actions for the benefit of investors. Investment managers (managing companies) can be in the form of: (1) Security companies, which are generally in the form of a separate division or PT which specifically handles mutual funds; and (2) Companies that are specifically engaged as investment management companies (PMI) or investment management companies;

b. A custodian bank is part of the business activities of a bank that acts as a safe keeper as well as a mutual fund administrator. The funds raised from many investors are not part of the investment manager's wealth or the custodian bank's assets, but belong to the investors who are kept in the name of mutual funds from the custodian bank. Both the investment manager and the custodian bank that will carry out this activity must first obtain permission from Bapepam;

c. Actors (intermediaries) in the capital market (broker, underwriter) and money market (banks) and supervisors conducted by Bapepam. ${ }^{14}$

Rights and Obligations of the Parties in Sharia Mutual Funds The rights of investors as stated in the DSN 20 / DSN-MUI / IX / 2000 fatwa are as follows:

a. The agreement between the investor and the investment manager is conducted in wakalah;

b. Akad wakalah, investors mandate investment managers to carry out the investments for the interests of investors, in accordance with the provisions set forth in the prospectus; Prospectus is any written information relating to a public offering with the aim of getting other parties to buy securities;

c. The investors collectively have the right to return on investment in Islamic mutual funds;

d. The investors bear relevant risks in shariah mutual funds;

${ }^{13}$ M. Rasyid Ridha, dkk, Peranan Reksadana Syariah dalam Peningkatkan Investasi di Indonesia, Jurnal Hukum Ekonomi, Vol. 2, No. 2, 2013.

14 Sofiani Ghufron, Investasi Halal di Reksa Dana Syari'ah, Jakarta: Renaisan, 2005,p. 16. 
e. The investors are entitled to add or withdraw their participation in Islamic mutual funds at any time through an investment manager;

f. Investors are entitled to share returns on investment until such investment is withdrawn;

g. The investors who have provided funds will receive a guarantee that all funds will be deposited, guarded and supervised by the Custodian Bank; Custodian Bank is a party whose business activities are to provide custodian services for securities and other assets related to securities and other services, including receiving dividends and other rights, completing security transactions, and representing account holders who become their customers;

h. Investors will receive proof of ownership in the form of Islamic mutual fund units.

The most important instrument in mutual funds is the investment prospect. The investment manager bases his decision on this instrument in these mutual funds. There are several mutual fund models being developed:

a. Fixed income mutual funds without stock elements, means that the mutual fund takes an investment strategy with the aim of maintaining the initial value of capital and earning a fixed income;

b. Fixed income mutual funds-with stock elements, mutual funds which if the investment allocation is determined at least $80 \%$ of its asset value is invested in debt securities and the remainder can be invested in debt securities as well;

c. Equity mutual funds, this mutual fund is also known as an equity type of mutual fund;

d. Mixed mutual funds can be called as free mutual funds in determining the allocation of assets, so that at any time they have an investment portfolio with a majority of shares and it can also be bonds. ${ }^{15}$

Based on the DSN fatwa No. 20 / DSN-MUI / IV / 2001, there are two operational mechanisms in the implementation of sharia mutual funds. They are the operational mechanism between investors and investment managers and operational mechanisms between investment managers and investment users. The operational mechanism between investors and investment managers is carried out using the wakalah system. The characteristics of the wakalah system are:

a. The agreement between the investor and the investment manager is made in wakalah;

b. With the wakalah contract, investors mandate investment managers to carry out investments for the interests of investors, in accordance with the provisions stated in the prospectus;

15 Pontjowinoto, Investasi dalam Reksa Dana Syariah, Yogyakarta, 1997, p. 8-7. 
c. Investors collectively have the right to return on investment in Islamic mutual funds;

d. Investors bear relevant risks in shariah mutual funds;

e. Investors are entitled to add or withdraw their participation in Islamic mutual funds at any time through an investment manager;

f. Investors are entitled to the share returns on investment until such investment is withdrawn;

g. Investors who have provided their funds will get a guarantee that all their funds will be kept, guarded and supervised by the custodian bank;

h. Investors will receive proof of ownership in the form of Sharia Mutual Fund Participation Units.

Meanwhile, the operational mechanism between investment managers and investment users is carried out using the mudarabah system. The characteristics of the mudarabah system are as follows: (a) Profit sharing between investors (sahibul mal) represented by the investment manager and investment users based on a proportion that has been agreed by both parties through the investment manager as a representative and there is no guarantee of certain investment returns to investors ; (b) Investors only bear the risk of the funds that have been given; (c) The investment manager as a representative does not bear the risk of loss on his investment as long as it is not due to negligence (gross negligence/tafrit).

Investment income that can be received in Islamic mutual funds are as follows:

a. From shares in the form of: a) Dividends in the form of profit sharing divided from profits, either paid in cash or in the form of shares; b) Right which is the right to pre-empt securities granted by the issuer; c) Capital gain, which is the profit obtained from buying and selling shares in the capital market.

b. From bonds that comply with sharia: profit sharing received periodically from the issuer's profit.

c. From money market securities in accordance with sharia: profit sharing received by the issuer.

d. From deposits, it can be in the form of: profit sharing received from Islamic banks. ${ }^{16}$

\section{The Form of Sharia Mutual Fund Applicative Forms}

Sharia mutual funds are mutual funds that operate according to the provisions in sharia principles, both in the form of contracts, fund management, and the use of funds. The form of the contract between the investor and the institution should be carried out using the mudharabah system, where the first party provides all $(100 \%)$ of the capital while the

16 Abdul Manan, Aspek Hukum dalam Penyelenggaraan Investasi di Pasar Modal Syariah Indonesia, p. 167. 
other party becomes the manager, the profits from the business are shared according to the agreement set forth in the contract, whereas if the loss is borne by the owner of the capital for the loss not due to negligence of the manager, but if it is caused by negligence of the manager, then the manager is responsible for the loss.

In carrying out its operations, Islamic mutual funds must remain within the corridor of sharia. First, it must determine the object which is valid and lawful. This stage is carried out by investment managers by only placing funds in sharia securities. Second, determine the process carried out with sharia principles. Including the validity of the contract and it does not contain usury elements. As explained in the DSN fatwa No. 20 / DSN-MUI / IV / 2001 that investors and investment managers use a wakalah contract, in which investors mandate investment managers to carry out investment activities for the investors' benefit in accordance with the provisions set out in the Mutual Fund Prospectus. Meanwhile, investors who carry out mudharabah contracts with investment managers are in accordance with the DSN fatwa No. 20 / DSN-MUI / IV / 2001 which states that investment managers and custodian banks are entitled to receive service fees calculated on a certain percentage of the net asset value of Islamic mutual funds. Third, emphasizing the results of the two previous processes, this must be guaranteed their validity and halalness.

\section{Analysis of Sharia Economic Law on Mutual Funds}

The existence of Islamic mutual funds, complements the diversity of mutual funds, and is an investment choice for investors, especially Muslim investors. In carrying out investment activities, Islam does not only see optimization or even maximization of the final result. The initial intention and the process that is then followed must remain on the syar'i path. One of the basic guidelines is contained in Qur'an Surah An-Nisa verse 29 which means: " $O$ people who believe, do not eat each other's wealth in a way that is vanity, except by the way of commerce that applies equally you, and do not kill yourselves; Indeed, Allah is Most Merciful to you."17

The question is, how is it meant to transact properly according to the Shari'ah, and not to fall into the category, "consuming the property of one another in vain?" Islamic law stipulates that in every contract there must be ridhaiyyah or a condition of mutual pleasure. In addition, the transactions allowed by Shariah are the halal of goods and are avoided from gharar, riba, and maysir.

Apart from how to properly transact in investing, there is also legal protection for investors in implementing mutual fund operations. Mutual funds have 2 (two) forms; Mutual Funds in the form of Companies and Collective Investment Contract Mutual Funds, because there are 2 (two) forms based on the management contract, so when talking about aspects of

17 Saifuddin, Terjemah Tafsir Perkata, p. 83. 
legal protection, we will also talk about slightly different matters. Legal protection for the Company's Mutual Fund investors as stipulated in the Mutual Fund Management Agreement between the Company and the Investment Manager and the Custodian Agreement with the Custodian Bank. Investors also receive legal protection from the capital market law and its implementing regulations, especially the Bapepam Regulations and Fiduciary duty.

Legal protection provided for Mutual Fund Investors of the Company according to the provisions of the laws and regulations in:

a. Bapepam Regulation No.IV.A.3 point 1 letter (g) states: Mutual funds in the form of companies that have obtained a business license must meet the following conditions: the Investment Manager must submit all reports, notes and other material and relevant information to the board of directors, and is required to provide other information related to Mutual Fund management requested by the board of directors to evaluate the Mutual Fund Management Contract;

b. Bapepam Regulation No.IV.A.3 point 11 states: Investment Managers are required to maintain all important records relating to financial reports and mutual fund management as stipulated by the Capital Market Supervisory Agency;

c. Bapepam Regulation No. IV.A.5 point 4 states: Custodian Bank is obliged to administer Securities and funds from Mutual Funds, provides custodian services for securities and other assets related to securities and other services, including receiving dividends, interest, other rights and completes Securities transactions;

d. Bapepam Rule No.IV.A.5 point 7 states: Custodian Bank is obliged to carry out registration, change of name in securities ownership, distribution of rights related to Mutual Fund shares.

The forms of legal protection contained in the agreement (KIK), Regulation of the Capital Market Supervisory Agency and fiduciary duty are:

a. The Investment Manager calculates the net asset value of KIK Mutual Funds every day and then announces it to the Investor or the unit holder;

b. The Investment Manager must submit reports regularly to the Capital Market Supervisory Agency and Investors or Participation Unit holders. Thus, the Capital Market Supervisory Agency can regularly supervise KIK Mutual Fund activities, and investors or unit holders receive information disclosure;

c. The Investment Manager has assets that are separated from the assets in KIK Mutual Funds. The Investment Manager is kept by the Custodian Bank. In this case the Custodian Bank has the right not to issue funds if it 
is not in accordance with the provisions in the KIK Mutual Fund establishment agreement;

d. Investment Manager may not be affiliated with Custodian Bank. This can eliminate the risk of manipulation by the Investment Manager and the Custodian Bank;

e. Bapepam regulation governs the actions that investment managers may not take. If KIK Mutual Funds, in this case represented by an Investment Manager, take actions that is forbidden and harm investors or Participation Unit holders, the Capital Market Supervisory Agency may freeze or dissolve the KIK Mutual Funds;

f. The Investment Manager is obliged to distribute liquidation funds proportionally to investors or Participation Unit holders in the event that KIK Mutual Funds are liquidated.

As an effort to protect investors and fulfill the principles of full and fair disclosure, the Investment Manager and the Custodian Bank need to be subjected to a legal audit (legal audit) concerning the validity of documents such as Articles of Association, Business Permits, and good cases, civil and criminal cases involving Investment Managers and Custodian Banks. The results of the legal examination will be used as the basis for providing a legal opinion regarding the condition that the Investment Manager and Custodian Bank can act in accordance with their respective functions to guarantee the interests of the Participation Unit. Maturity and maturity of investors in carrying out activities in the Capital Market sector are constantly being demanded, not to be too vulnerable to rumors and issues created by irresponsible parties, and to be more trained in analyzing investment risks and reading things that previously could not be predicted to be something that can be processed and able to make the right and safe decisions.

\section{Closing}

Sharia mutual funds are one of the Islamic financial instruments that are currently developing, so investing in mutual funds is an alternative investment for people who want to get investment returns from clear sources. Returns investment can be known without having to participate in investing with the availability of return reports from investment managers or other parties who provide investment places or services. So mutual funds exist as a forum that can be used as investors or parties who want to invest, but have limited time and knowledge.

In carrying out transactions, sharia mutual funds are not allowed to carry out speculative acts, which contain gharar, such as najsy (fake offers), ihtikar and other acts of speculation. The operational mechanism in Islamic mutual funds can be divided into two. They are between investors and investment managers, and between investment managers and investment 
users. To ensure sharia mutual funds operate without violating the rules as stipulated in the fatwa of the National Sharia Council (DSN), a sharia mutual fund must hold 3 principles in its management. That is; (1) investing in sharia securities; (2) there is a cleansing process; (3) there is a Sharia Supervisory Board. 


\section{Bibliography}

Haerisma, Alvien Septian. Pengantar Reksadana Syariah Introduction of Islamic Mutual Fund.

HR. Abu Daud, Ibnu Majah dan Tirmizy dari Amru bin 'Auf, lihat Abdul Manan, Aspek Hukum dalam Penyelenggaraan Investasi di Pasar Modal Syariah Indonesia.

Ghufron, Sofiani ed, Briefcase Book Edukasi Profesional Syari'ah Investasi Halal di Reksadana Syari'ah, Jakarta: Renaisan, 2005.

Manan, Abdul, Aspek Hukum dalam Penyelenggaraan Investasi di Pasar Modal Syariah Indonesia, Jakarta: Kencana, 2009.

Muhammad, Dasar-dasar Keuangan Islami, Yogyakarta: Ekonisia, 2004.

Nugroho, Haddad Adjie, Minat Masyarakat terhadap Reksadana Syariah: Peran Religiusitas, Literasi Finansial dan Pendapatan, Skripsi, Yogyakarta: Universitas Islam Indonesia, 2020.

Pontjowinoto, Investasi dalam Reksadana Syariah, Yogyakarta, 1997.

Ridha, M. Rasyid Ridha, dkk, Peranan Reksadana Syariah dalam Peningkatkan Investasi di Indonesia. Jurnal Hukum Ekonomi, 2013.

Saifuddin, Muhammad. Terjemah Tafsir Perkata. Bandung: Sygma, 2010.

Umar, Hasbi, Filsafat Fiqh Muamalat Kontemporer, Jakarta: PT Raja Grafindo Persada, 2014. 